\title{
ORDER FORM
}

\section{THE SPANISH JOURNAL OF PSYCHOLOGY}

Please enter my annual subscription (2010) at the following rate:

Individual Rate

$\begin{array}{ll}\text { Spain } & \square 36 \text { euros } \\ \text { Europe } & \square 42 \text { euros } \\ \text { Other Countries } & \square 48 \text { euros }\end{array}$

Institutional Rate

$\square 42$ euros

$\square 48$ euros

54 euros
Single Issue

$\square 15$ euros

$\square 18$ euros

$\square 21$ euros

\section{Method of Payment}

$\square$ Bank money order payable to:

Tesorería UCM - Recaudatoria - Cultura, Deporte y Política Social

Caja de Madrid

Alberto Alcocer, 46, 28016 Madrid (Spain)

To account No.: 2038 / $5837 / 91 / 6000618065$

\section{Credit Card}

$\square$ Visa
$\square$ Mastercard

Card No:

Expiry Date:

Signature:

Date:

Country:

Send this order form to: Servicio de Publicaciones

Universidad Complutense

Vicerrectorado de Cultura y Deporte

Obispo Trejo, 2

28040 Madrid (Spain) 


\section{Instructions to Authors}

Preparing Manuscripts. Authors should prepare manuscripts according to the Publication Manual of the American Psychological Association (5th ed.). Typing instructions and instructions on preparing tables, figures, references, metrics, and abstracts appear in the Manual (consult Appendix A, Checklist for Manuscript Submission, as a guide). You may also check http://www.apa.org/journals/authors/manuscript_check.html. Manuscripts should be written in English, Spanish, Portuguese or Russian. Accepted Spanish, Portuguese or Russian manuscripts will be translated and published in English. All copy must be double-spaced, with a maximum of 30 pages (DIN A4). Figures, tables, and footnotes should be supplied on separate pages, and referred to in the text. References should be listed at the end of the manuscript and referred to in the text by name and year. All manuscripts should have two title pages: the first one with the short title, the full title, the author's name, affiliation, date of postage, and author's address; the second title page should only show the short title, the full title, and the postage date. All manuscripts are subject to editing for sexist language.

Abstracts. Manuscripts of articles must be accompanied by a 150-200 word abstracts in English. The abstracts should be a summary of the whole manuscript, not only of its conclusions. Each abstract must be typed on a separate page. A list of 4-5 key words should be provided directly below the abstract. Key words should express the precise content of the manuscript.

Submitting Manuscripts. Submission implies that the manuscript has not been published and is not currently under consideration for publication elsewhere. A statement transferring copyright to The Spanish Journal of Psychology will be required before the manuscript can be accepted for publication. Manuscripts should be accompanied by the corresponding cover letter. In addition to addresses, affiliation, and phone numbers, the cover letter should include electronic mail addresses and fax numbers, if available, for potential use by the editorial office and later by the production office. Authors should keep a copy of the manuscript to guard against loss. The first author will receive twenty-five (25) off-prints of the paper. Additional copies in multiples of fifty (50) may be purchased by filling out an off-print order form which will be sent with the proofs to the author. Mail manuscripts to the Editor.

\section{Javier Bandrés \\ psyjour@psi.ucm.es}

Selection Process. Since the reviewing process will be masked, the author's name should appear only on the accompanying cover letter, and the first title page, but not on the second title page, the abstract, nor in the article itself. Authors should make every effort to ensure that the manuscript itself contains no clues to their identities (any footnotes containing information pertaining to the authors' identity or affiliations, etc., should be on separate pages). Manuscripts will not be returned to the author. The Spanish Journal of Psychology guarantees that submited articles will be reviewed within a 3 month period.

Ethical Standards. The Journal suscribes to the ethical standars of the APA, within the legal framework of Spain. Authors are reminded that, once a manuscript has been submitted for publication, it should not be sent off for concurrent consideration by any other journals. 


\section{THE SPANISH JOURNAL OF PSYCHOLOGY}

\section{CONTENTS}

Articles

393 Yale University's Institute of Human Relations and the Spanish Civil War: Dollard and Miller's Study of Fear and Courage under Battle Conditions. José Maria Gondra and Manuel Sánchez de Miguel

405 Acceptance and Confidence of Central and Peripheral Misinformation Karlos Luna and Malen Migueles

414 Enhanced Processing of Emotional Gist in Peripheral Vision. Aida Gutiérrez, Lauri Nummenmaa, and Manuel G. Calvo

424 Using Latent Semantic Analysis and the Predication Algorithm to Improve Extraction of Meanings from a Diagnostic Corpus. Guillermo Jorge-Botana, Ricardo Olmos, and José Antonio León

441 Changes in Reading Strategies in School-Age Children. Gretel Sanabria Díaz, María del Rosario Torres, Jorge Iglesias, Raysil Mosquera, Vivian Reigosa, Elsa Santos, Agustín Lage, Nancy Estévez. and Lidice Galán

454 Effects of the History of Adoption in the Emotional Adjustment of Adopted Adolescents. Caroline Tozzi Reppold, and Claudio Simon Hutz

462 School Adjustment of Children in Residential Care: a Multi-Source Analysis. Eduardo Martín, and María del Carmen Muñoz de Bustillo

471 Characteristics of Sexual Behavior in Spanish Adolescents. Inmaculada Teva, $\boldsymbol{M}^{a}$ Paz Bermúdez, and Gualberto Buela-Casal

485 Gender Differences in HIV-Related Sexual Behavior among College Students from Spain and Portugal. Alicia Muñoz-Silva, Manuel Sánchez-Gurcía, Ana Martins, and Cristina Nunes

496 Understanding Discipline in Families of Children with AttentionDeficit/Hyperactivity Disorder: A Structural Equation Model. Ana Miranda, Dolores Grau, Jesús Rosel and Amanda Meliá

506 Parenting Cultural Models of a Group of Mothers from Rio de Janeiro. Maria Lucia Seidl-de-Moura, Tatiana Targino Alves Bandeira, Katia Nahum Campos, Edilaine Moreno da Cruz, Gabriela dos Santos Amaral, and Renata Gomes da Costa de Marca

518 Estimating One's Owri and One's Relatives' Multiple Intelligence: A Cross-Cultural Study from East Timor and Portugal. Félix Neto, Adrian Furnham, and Maria da Conceição Pinto

528 Estimates of Self, Parental, and Partner Multiple Intelligence and their Relationship with Personality, Values, and Demographic Variables: A Study in Britain and France. Viren Swami, Adrian Furnham, and Susan Zilkha

540 Intensity of Habitual Guilt in Men and Women: Differences in Interpersonal Sensitivity and the Tendency towards AnxiousAggressive Guilt. Itziar Etxebarria, M. José Ortiz, Susana Conejero, and Aitziber Pascual

555 Individualism and Collectivism: What Differences between Portuguese and Romanian Adolescents? Laura Ciochină and Luísa Faria

565 Social Representations, Risk Behaviors and AIDS. Brigido Vizeu Camargo, and Andréa Barbará S. Bousfield

576 Social Norms and Prejudice against Homosexuals. Annelyse Pereira, Maria Benedicta Monteiro, and Leoncio Camino

585 Social Support, Burnout Syndrome and Occupational Exhaustion among Mexican Traffic Police Agents. Carolina Aranda Beltrán, Manuel Pando Moreno, José G. Salazar Estrada, Teresa M. Torres López, and María Guadalupe Aldrete Rodríguez

593 Stress and Quality of Life of Senior Brazilian Police Officers. Marilda E. Novaes Lipp

604 Development of an Implicit Overall Well-Being Measure Using the Implicit Association Test. Dario Diaz, Javier Horcajo, and Amalio Blanco

618 The Source of Display Rules and their Effects on Primary Health Care Professionals' Well-Being. David Martinez-Iñigo, Peter Totterdell, Carlos Maria Alcover, and David Holman

632 Employability and Personal Initiative as Antecedents of Job Satisfaction. Juan Pablo Gamboa, Francisco Gracia, Pilar Ripoll, and José María Peiró
641 Work, Family, and Gender: Elements for a Theory of Work-Family Balance. Leonor M. Cantera, $M^{a}$ Eugenia Cubells, Luz $M^{a}$ Martinez, and Josep M. Blanch

648 Public Responses to Intimate Partner Violence Against Women: The Influence of Perceived Severity and Personal Responsibility. Enrique Gracia, Fernando García, and Marisol Lila

657 Putting Text in Context: The Conflict between Pro-Ecological Messages and Anti-Ecological Descriptive Norms. Luis Oceja and Jaime Berenguer

667 Leadership in Nonprofit Organizations of Nicaragua and El Salvador: A Study from the Social Identity Theory. Juan Antonio Moriano León, Gabriela Topa Cantisano, and Jean-Pierre Lévy Mangin

677 Visoconstructive Deficits and Risk of Developing Eating Disorders. Nayelli Alvarado-Sánchez, Cecilia Silva-Gutiérrez, and Judith Salvador-Cruz

686 Speech and Language Pathology and Autistic Spectrum. Carla Cardoso and Melaine Luz Montenegro

696 Emotional Distress in Parents of Psychotic Patients is Modified by Serotonin Transporter Gene (5-HTTLPR) - Brain-Derived Neurotrophic Factor Gene Interactions. Vera Golimbet, Margarita Alfimova, Galina Korovaitseva, Lilia.I. Abramova, and Vasily G. Kaled

707 Salivary Cortisol Response to a Psychosocial Stressor on Children Diagnosed with Attention-Deficit/Hyperactivity Disorder: Differences Between Diagnostic Subtypes. Enrique F. Maldonado, $M^{a}$ Victoria Trianes, Antonio Cortés, Encarnación Moreno, and Milagros Escobar

715 Features of Color Reflection in Psychogenic Pain in Patients with Somatoform Disorders during Psychotherapeutic Treatment. Vera A. Ishinova, Irina A. Svyatogor and Tatiana N. Reznikova

725 Temporal Stability and Cross-National Consistency of the Dimensional Structure of the Sexual Attraction Questionnaire (SAQ). Juan Fernández, $M^{a}$ Ángeles Quiroga, Isabel Del Olmo, Chiara Buizza and Antonio Imbasciati

737 Adaptation of the ESPA29 Parental Socialization Styles Scale to the Basque Language: Evidence of Validity. Alicia López-Jáuregui and Paula Elosua Oliden

746 Validation Study of the Spanish Version of the Work-Family Conflict Questionnaire (CCTF). Angel Blanch and Antón Aluja

756 Argentinean Adaptation of the Social Skills Inventory IHS-Del-Prette. Fabián Orlando Olaz, Leonardo Medrano, María Eugenia Greco, and Zilda Aparecida Pereyra Del Prette

767 Cross-Cultural Validation of the Work Values Scale EVAT Using Multi-Group Confirmatory Factor Analysis and Confirmatory Multidimensional Scaling. Luis M. Arciniega, Luis González, Vitor Soares, Stefania Ciulli, and Marco Giannini

773 Content Validity and Metric Properties of a Pool of Items Developed to Assess Humor Appreciation. Hugo Carretero-Dios, Cristino Pérez. and Gualberto Buela-Casal

788 Validity Evidence for the Reading Competence Test of Words and NonWords. Alessandra Gotuzo Seabra, Monalisa Muniz, and Ricardo Primi

799 Validation of the Spanish Version of the Situational Motivation Scale (EMSI) in the Educational Context. José Martín-Albo, Juan L. Núñez, and José G. Navarro

808 Self-Change Strategies in Smokers and Former Smokers: Spanish Adaptation of the SCS-CS and SCS-FS. José Luis Carballo, Roberto Secades-Villa, José Ramón Fernández-Hermida, Olaya GarcíaRodríguez, and $M^{a}$ Teresa Bobes-Bascarán

815 Psychometric Properties of the Revised Physical and Social Anhedonia Scales in Non-Clinical Young Adults. Eduardo Fonseca-Pedrero, Mercedes Paino, Serafín Lemos-Giráldez, Eduardo García-Cueto, Úrsula Villazón-García, Julio Bobes, and José Muñiz

823 Factors Affecting Visual Inference in Single-Case Designs. Verônica Morais Ximenes, Rumen Manolov, Antonio Solanas, and Vicenç Quera

833 The Hirsch $\mathrm{h}$ Index in a Non-Mainstream Area: Methodology of the Behavioral Sciences in Spain. Miguel A. García-Pérez 